\title{
Improving the bioavailability of nutrients in plant foods at the household level
}

\author{
Rosalind S. Gibson*, Leah Perlas ${ }^{\dagger}$ and Christine Hotz \\ Department of Human Nutrition, University of Otago, Dunedin, New Zealand
}

\begin{abstract}
Plant foods are the major staples of diets in developing countries, in which the consumption of animal-source foods is often low because of economic and/or religious concerns. However, such plant-based diets are often associated with micronutrient deficits, exacerbated in part by poor micronutrient bioavailability. Diet-related factors in plant foods that affect bioavailability include: the chemical form of the nutrient in food and/or nature of the food matrix; interactions between nutrients and other organic components (e.g. phytate, polyphenols, dietary fibre, oxalic acid, protein, fat, ascorbic acid); pretreatment of food as a result of processing and/or preparation practices. Consequently, household strategies that reduce the content or counteract the inhibiting effects of these factors on micronutrient bioavailability are urgently needed in developing-country settings. Examples of such strategies include: germination, microbial fermentation or soaking to reduce the phytate and polyphenol content of unrefined cereal porridges used for young child feeding; addition of ascorbic acid-containing fruits to enhance non-haem-Fe absorption; heating to destroy heat-labile anti-nutritional factors (e.g. goitrogens, thiaminases) or disrupt carotenoid-protein complexes. Such strategies have been employed in both experimental isotope-absorption and community-based studies. Increases in $\mathrm{Fe}, \mathrm{Zn}$ and $\mathrm{Ca}$ absorption have been reported in adults fed dephytinized cereals compared with cereals containing their native phytate. In community-based studies in rural Malawi improvements in dietary quality and arm-muscle area and reductions in the incidence of anaemia and common infections in young children have been observed.
\end{abstract}

Bioavailability: Plant foods: Household: Micronutrients: Phytate

In developing countries plant foods are the major staples of the diet and consumption of animal-source foods is often low because of economic and/or religious concerns. Such plant-based diets are, however, often associated with deficits in $\mathrm{Ca}, \mathrm{Fe}, \mathrm{Zn}$ and some vitamins. A major factor contributing to these deficits, particularly for diets based on unrefined cereals and legumes, is that bioavailability, which can be defined as the proportion of an ingested trace element in food that is absorbed and utilized for normal metabolic and physiological functions or storage (Jackson, 1997), is poor. Bioavailability is influenced by both dietary and host-related factors (Fairweather-Tait \& Hurrell, 1996). The present review addresses the dietary factors and summarizes food preparation and processing practices that can be used in the household to enhance nutrient bioavailability. Examples of efficacy studies employing these strategies in developing countries are also given.

\section{Diet-related factors in plant foods that affect bioavailability}

Several dietary factors may affect the nutrient bioavailability of plant foods when they are consumed, including: (1) the chemical form of the nutrient in the food and the nature of the food matrix; (2) interactions occurring between nutrients and other organic components within the plant food; (3) pretreatment of the food during processing and/or preparation.

*Corresponding author: Professor R. S. Gibson, fax + 643479 7958, email Rosalind.Gibson@stonebow.otago.ac.nz

†resent address: Food and Nutrition Research Institute, Department of Science and Technology, Bicutan, Taguig, Metro Manila, Philippines.

$\nmid$ Present address: HarvestPlus, c/o International Food Policy Research Institute, 2003 K Street, NW, Washington DC 20006-1002, USA. 
Table 1. Effects of non-competitive interactions involving organic substances on nutrient bioavailability in plant foods: inhibiting factors

\begin{tabular}{|c|c|c|c|}
\hline Dietary component & Food sources & Main technical influences & Nutritional consequences \\
\hline $\begin{array}{l}\text { Phytate (myo-inositol } \\
\text { hexaphosphate) plus } \\
\text { magnesium, calcium } \\
\text { or potassium phytate }\end{array}$ & $\begin{array}{l}\text { Unrefined cereals, legumes, } \\
\text { nuts, oil seeds }\end{array}$ & $\begin{array}{l}\text { Binds certain cations to form } \\
\text { insoluble complexes in gut }\end{array}$ & $\begin{array}{l}\text { Zn, Fe, Ca and probably Mg are poorly } \\
\text { absorbed (Heaney et al. 1991; } \\
\text { Sandberg et al. 1999) }\end{array}$ \\
\hline Soyabean protein & $\begin{array}{l}\text { Some varieties of soyabeans, } \\
\text { unfermented tofu, } \\
\text { textured vegetable protein }\end{array}$ & $\begin{array}{l}\text { Effect not explicable on basis of } \\
\text { phytate content but instead depends } \\
\text { on variety and processing method }\end{array}$ & $\begin{array}{l}\text { Inhibits } \mathrm{Fe} \text { and } \mathrm{Zn} \text { absorption in some } \\
\text { varieties. Some contain Fe as } \\
\text { phytoferrin, which may be highly } \\
\text { bioavailable (Murray-Kolb et al. 2003) }\end{array}$ \\
\hline Polyphenols & $\begin{array}{l}\text { Certain cereals (red sorghum), } \\
\text { legumes (red kidney beans, } \\
\text { black beans, black grams), } \\
\text { spinach, betel leaves, oregano } \\
\text { Beverages: tea, coffee, cocoa, } \\
\text { red wine }\end{array}$ & $\begin{array}{l}\text { Form insoluble complexes with Fe } \\
\text { Some polyphenols inactivate thiamin } \\
\text { Bind certain salivary and digestive } \\
\text { enzymes } \\
\text { Enhance excretion of endogenous } \\
\text { protein }\end{array}$ & $\begin{array}{l}\text { Inhibit non-haem-Fe absorption } \\
\text { Reduce thiamin absorption } \\
\text { Reduce digestibility of starch, protein } \\
\text { and lipids } \\
\text { Interfere with protein digestibility } \\
\text { (Bravo, 1998) }\end{array}$ \\
\hline Oxalic acid & $\begin{array}{l}\text { Amaranth, spinach, rhubarb, yam, } \\
\text { taro, sweet potato, sorrel, } \\
\text { sesame seeds, black tea }\end{array}$ & $\begin{array}{l}\text { Oxalates form insoluble complexes } \\
\text { with } \mathrm{Ca} \text { and possibly } \mathrm{Fe}\end{array}$ & $\begin{array}{l}\text { Reduce absorption of } \mathrm{Ca} \text { and } \\
\text { possibly Fe; increase urinary } \\
\mathrm{Ca} \text { (Savage, 2002) }\end{array}$ \\
\hline \multirow[t]{3}{*}{ Dietary fibre } & $\begin{array}{l}\text { Unrefined cereals, legumes, nuts, } \\
\text { oil seeds, fruits and vegetables }\end{array}$ & Lignin and pectin bind bile acids & $\begin{array}{l}\text { Reduces absorption of fats, fat-soluble } \\
\text { vitamins and carotenoids; effects on } \\
\text { folate bioavailability inconsistent }\end{array}$ \\
\hline & & $\begin{array}{l}\text { Pectins, psyllium and gums retain } \\
\text { water and form viscous solutions } \\
\text { in gastrointestinal tract }\end{array}$ & $\begin{array}{l}\text { Slows gastric emptying and digestion } \\
\text { and absorption of nutrients (Gallagher } \\
\text { \& Schneeman, 2001) }\end{array}$ \\
\hline & & $\begin{array}{l}\text { Dietary fibres are fermented in large } \\
\text { intestine by microflora }\end{array}$ & $\begin{array}{l}\text { SCFA produced that enhance Ca } \\
\text { solubility (Demigne et al. 1995) }\end{array}$ \\
\hline
\end{tabular}

Sorghum, Sorghum bicolor (L.) Moench; red kidney beans, Phaseolus vulgaris; black beans, Glycine max; black gram, Phaseolus mungo; spinach, Spinacia oleracea; betel, Piper betel; oregano, Origanum vulgare; amaranth, Amaranthus edulis; rhubarb, Rheum rhaponticum; yam, Dioscorea spp.; taro, Colocasia esculenta var. antiquorum; sweet potato, Ipomoea batatas; sesame, Sesamum orietale.

In general, diet-related factors have a greater influence on the bioavailability of the micronutrients in plant foods, particularly $\mathrm{Ca}$, Fe and $\mathrm{Zn}$, than on the macronutrients. The absorption of $\mathrm{Ca}, \mathrm{Fe}$ and $\mathrm{Zn}$ is particularly affected. The net effect on the nutrient bioavailability depends on the balance between factors that either inhibit or enhance nutrient absorption and/or utilization in the whole diet (Sandström, 2001). Increasingly, the influence of both synthetic micronutrient fortificants and intrinsic micronutrients on micronutrient bioavailability must be considered.

\section{Chemical form of the nutrient and nature of the dietary matrix}

The absorption and/or utilization of the trace elements $\mathrm{Fe}$, Se and $\mathrm{Zn}$, and of the vitamins niacin, provitamin $\mathrm{A}$ carotenoids and folate are most affected by their chemical form. Of these micronutrients, the bioavailability of the two forms of $\mathrm{Fe}$ in food (haem- and non-haem-Fe; Hallberg, 1981), certain isomeric forms of carotenoids (Yeum \& Russell, 2002) and folate polyglutamates relative to monoglutamates (McNulty \& Pentieva, 2004) have been reviewed in detail elsewhere.

The food matrix probably has the greatest effect on the absorption of provitamin A carotenoids and folate, both of which can be entrapped in the insoluble plant matrix, thus reducing their bioavailability. For example, $\beta$-carotene in raw carrots or lycopene in fresh tomato juice are poorly absorbed compared with pure $\beta$-carotene dissolved in oil (Yeum \& Russell, 2002), whereas the bioavailability of folate from chopped spinach (Spinacia oleracea) is higher than that from whole spinach leaves (Castenmiller et al. 2000).

\section{Interactions between nutrients themselves and with other organic components in the plant food}

Direct competitive interactions between two (or more) inorganic nutrients with similar physico-chemical properties that share the same absorptive pathways are unlikely in plant foods because the intrinsic micronutrient levels are low. Even when plant staples serve as vehicles for fortification the risk of such interactions is small because of the presence of dietary ligands in food (Sandström et al. 1985).

In contrast, there are several organic components in plant foods that may form insoluble or soluble complexes with certain micronutrients in the acid $\mathrm{pH}$ of the stomach and gastrointestinal tract, thus inhibiting or facilitating their absorption. Re-absorption of endogenously-excreted $\mathrm{Ca}, \mathrm{Zn}$ and $\mathrm{Cu}$ may also be affected (Sandström, 2001; Manary et al. 2002a). Examples of these non-competitive interactions are summarized in Tables 1 and 2; both inhibiting and enhancing factors are listed. 
Table 2. Effects of non-competitive interactions involving organic substances on nutrient bioavailability in plant foods: enhancing factors

\begin{tabular}{|c|c|c|c|}
\hline Dietary component & Food sources & Main technical influences & Nutritional consequences \\
\hline $\begin{array}{l}\text { Organic acids (citric, lactic, } \\
\text { acetic, butyric, propionic } \\
\text { and formic acids) }\end{array}$ & $\begin{array}{l}\text { Fermented milk products } \\
\text { (e.g. yoghurts), vegetables, } \\
\text { sauerkraut, soya sauces, } \\
\text { fermented cereals } \\
\text { (e.g. Tobwa) }\end{array}$ & $\begin{array}{l}\text { May form soluble ligands with } \\
\text { some trace minerals in the } \\
\text { gastrointestinal tract }\end{array}$ & $\begin{array}{l}\text { Enhance absorption of } \mathrm{Zn} \text { and } \\
\text { possibly Fe (Sandström, 1997; } \\
\text { Teucher et al. 2004) }\end{array}$ \\
\hline Ascorbic acid & $\begin{array}{l}\text { Citrus fruits and juices } \\
\text { Other fruits: guavas, mango, } \\
\text { papayas, kiwi, strawberries } \\
\text { Vegetables: tomato, asparagus, } \\
\text { Brussels sprouts, spinach etc. }\end{array}$ & $\begin{array}{l}\text { Reduces } \mathrm{Fe}^{3+} \text { to more soluble } \\
\mathrm{Fe}^{2+} ; \text { forms } \mathrm{Fe} \text {-ascorbate } \\
\text { chelate } \\
\text { May increase stability of folate } \\
\text { during food processing and } \\
\text { digestion }\end{array}$ & $\begin{array}{l}\text { Enhances non-haem-Fe absorption } \\
\text { (Teucher et al. 2004) } \\
\text { Counteracts inhibitory effect } \\
\text { of phytate } \\
\text { May enhance folate bioavailability } \\
\text { (McNulty \& Pentieva, 2004) } \\
\text { May enhance or inhibit Se absorption, } \\
\text { depending on the chemical form } \\
\text { (Mutanen \& Mykkanen, 1985; } \\
\text { Levander, 1987). } \\
\text { Ascorbic acid may also enhance } \\
\text { Cr absorption (Offenbacher, 1994) }\end{array}$ \\
\hline Protein & & $\begin{array}{l}\text { Amount and type (e.g. animal } \\
\text { protein) form soluble ligands } \\
\text { with } \mathrm{Zn}, \mathrm{Fe} \text { and } \mathrm{Cu}\end{array}$ & $\begin{array}{l}\text { Enhance absorption of Zn, Fe and } \\
\text { Cu (Bjorn-Rasmussen \& Hallberg, } \\
\text { 1979; Turnlund et al.1983; } \\
\text { Lönnerdal, 2000) } \\
\text { Increase urinary Ca excretion } \\
\text { (Heaney, 2000) }\end{array}$ \\
\hline Fat & Oil seeds, nuts & $\begin{array}{l}\text { Products of fat digestion + bile salts } \\
\text { solubilize fat-soluble vitamins } \\
\text { and carotenoids in intestinal milieu }\end{array}$ & $\begin{array}{l}\text { Enhance absorption of fat-soluble } \\
\text { vitamins and provitamin A } \\
\text { carotenoids (Yeum \& Russell, 2002) }\end{array}$ \\
\hline
\end{tabular}

Guava, Psidium guajava L.; mango, Mangifera indica L.; papaya, Carica papaya; kiwi, Actinidia deliciosa; strawberry, Fragaria $X$ ananassa; asparagus, Asparagus officinalis; spinach, Spinacia oleracea.

\section{Pretreatment of food in the household as a result of processing and/or preparation practices}

The adverse effects of some of the organic components in plant foods on nutrient bioavailability can be reduced by household food processing and preparation practices; these practices are summarized in Table 3 and will be discussed.

Thermal processing. This treatment generally enhances the digestibility of proteins and carbohydrates, although if Maillard browning occurs in baked foods protein quality and digestibility may be reduced (Table 3). Thermal processing may also improve the bioavailability of certain vitamins and I, in some cases because of the destruction of heat-labile anti-nutritional factors (Erdman \& PnerosSchneier, 1994). For example, thiaminases in Brussels sprouts and red cabbage, which catalyse the cleavage of thiamin, are destroyed by cooking (Hilker \& Somogyi, 1982). Cooking also destroys the goitrogens present in cabbage, Brussels sprouts, turnips, sweet potatoes (Ipomoea batatas), millet (hnatherum hymenoides), cassava (Manihot esculenta Crantz) and beans. Such goitrogens block the absorption or utilization of I and thus its uptake into the thyroid gland (Gaitan, 1990).

Thermal processing can also enhance the bioavailability of vitamins such as thiamin, vitamin $\mathrm{B}_{6}$, niacin and carotenoids by releasing them from entrapment in the plant matrix. For example, greater increases in total serum $\beta$-carotene and serum lycopene have been reported after eating cooked carrots and spinach (Rock et al. 1998) and cooked tomatoes (van het Hof et al. 2000) compared with levels when they are consumed raw. This effect is attributed to softening or disruption of plant cell walls and the disruption of carotenoid-protein complexes so that the carotenoids are more available in the intestinal lumen for absorption (Yeum \& Russell, 2002).

Reports on the effects of thermal processing on phytate degradation are inconsistent and depend on the plant species, temperature and/or pH. Hurrell et al. (2002) have reported that home thermal processing does not degrade phytate sufficiently to improve $\mathrm{Fe}$ absorption from homeprepared pancakes or chapattis. Other investigators (Kataria et al. 1989; Marfo et al. 1990; Khan et al. 1991) have suggested that conventional heat treatments such as boiling may induce moderate losses (i.e. 5-15\%) of phytic acid in tubers (Marfo et al. 1990) and some legumes (Kataria et al. 1989) and cereals (Khan et al. 1991). Much higher losses have been reported after boiling white rice (i.e. 70\%; Perlas \& Gibson, 2002), attributed mainly to leaching of water-soluble sodium, potassium or magnesium phytate into the discarded cooking water.

Germination. This process, also termed malting, leads to an increase in phytase activity in certain cereals (e.g. maize, millet and sorghum (Sorghum bicolor (L.) Moench)), in most legumes and in oil seeds through de novo synthesis and/or activation of intrinsic phytase. 
Table 3. Influence of household food processing and preparation methods on bioavailability of nutrients in plant foods

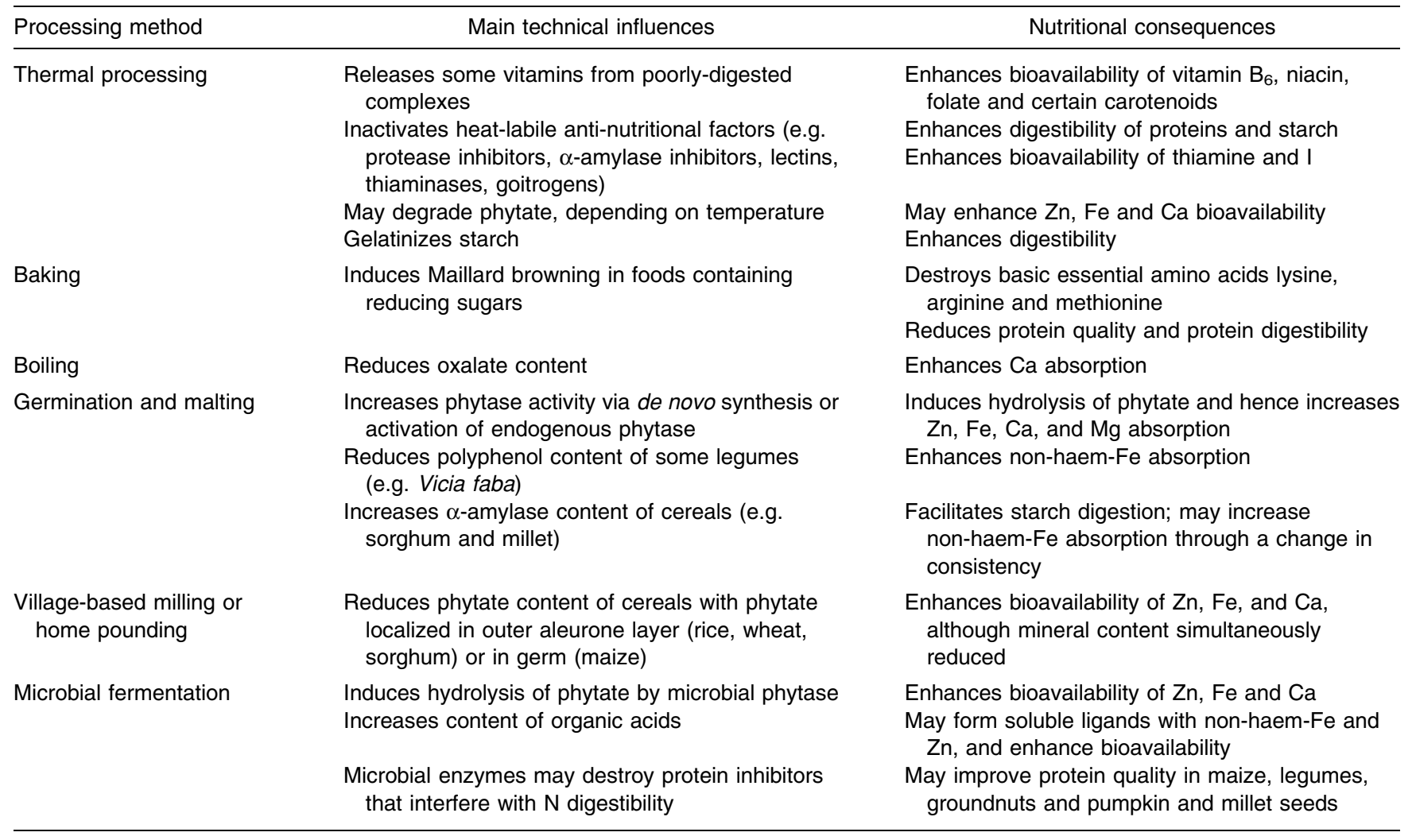

Sorghum, Sorghum bicolor (L.) Moench; millet, Achnatherum hymenoides; groundnut, Apios americana Medic.; pumpkin, Cucurbita Pepo.

Tropical cereals such as maize and sorghum have a lower endogenous phytase activity than do rye, wheat, triticale (X Triticosecale Wittmack), buckwheat (Fagopyrum esculentum) or barley (Egli et al. 2002). Phytases (myo-inositol hexakisphosphate 3-phosphohydrolase) hydrolyse phytic acid (myo-inositol hexaphosphate) as well as the salts, magnesium, calcium or potassium phytate, to yield inorganic orthophosphate and myo-inositol via intermediate myo-inositol phosphates (pentaphosphates to monophosphates). The rate of phytate hydrolysis varies with the species and variety, as well as the stage of germination, $\mathrm{pH}$, moisture content, temperature (optimal range 45$57^{\circ} \mathrm{C}$ ), solubility of phytate and the presence of certain inhibitors (Cheryan, 1980; Egli et al. 2003). Egli et al. (2002) have observed that during germination rice, millet and mungbean (Vigna radiata $\mathrm{L}$.) have the largest reductions in phytate content, ranging from $50 \%$ (for mungbeans) to $64 \%$.

Such reductions in the levels of higher inositol phosphates can have a major impact on mineral bioavailability because they form complexes with divalent and trivalent cations (particularly $\mathrm{Zn}, \mathrm{Fe}, \mathrm{Ca}$ and $\mathrm{Mg}$ ) at the physiological $\mathrm{pH}$ conditions of the small intestine, making them unavailable for absorption (Oberleas \& Harland, 1981; Hurrell, 2003; Egli et al. 2004; Hurrell et al. 2004); the higher inositol phosphates have no effect on $\mathrm{Cu}$ absorption (Egli et al. 2004). The hexa- and pentaphosphates may also complex endogenously-secreted minerals such as $\mathrm{Zn}$
(Sandström, 1997; Manary et al. 2000) and Ca (Morris \& Ellis, 1985), making them unavailable for re-absorption into the body. In contrast, myo-inositol phosphates with less than five phosphate groups (i.e. monophosphates to tetraphosphates) do not have a negative effect on $\mathrm{Zn}$ absorption (Lönnerdal et al. 1989) and those with less than three phosphate groups do not inhibit non-haem-Fe absorption (Sandberg et al. 1999). There appears to be no adaptation to the inhibitory effect of a high-phytate diet on absorption of Fe (Brune et al. 1989) or exogenous $\mathrm{Zn}$, although endogenous excretion of faecal $\mathrm{Zn}$ may be decreased in healthy subjects (Sandström et al. 1993).

Certain tannins and other polyphenols in legumes (e.g. Vicia faba) and red sorghum may also be reduced during germination as a result of the formation of polyphenol complexes with proteins and the gradual degradation of oligosaccharides (Camacho et al. 1992). Naturallyoccurring polyphenol oxidase extracted from banana (Musa X paridasiaca L.) or avocado (Persea americana Mill.) and subsequently reduced by dialysis has also been used to reduce the polyphenol content of high-tannin sorghum (Matuschek \& Svanberg, 2004).

$\alpha$-Amylase activity is also increased during germination of cereals, particularly sorghum and millet. This enzyme hydrolyses amylase and amylopectin to dextrins and maltose, thus reducing the viscosity of thick cereal porridges (Gibson \& Ferguson, 1998). A threefold increase in $\mathrm{Fe}$ absorption has been reported in amylase-treated 
roller-dried rice cereal compared with the untreated rollerdried cereal, which is associated with the viscosity changes induced by $\alpha$-amylase (Hurrell et al. 2002).

Milling or household pounding. In developing countries this process is used to remove the bran and/or germ from cereals such as wheat, sorghum, rice and maize. These processes also reduce the phytate content if the phytate is localized in the outer aleurone layer (e.g. rice, sorghum and wheat) or in the germ (i.e. maize; O'Dell et al. 1972). Milling can thus enhance mineral bioavailability, although the content of minerals and some vitamins of the milled cereals are simultaneously reduced. As a result, in some countries milled cereal flours are enriched to compensate for the micronutrients lost.

Microbial fermentation. Higher inositol phosphates are hydrolysed to lower inositol phosphates through the action of microbial phytase enzymes (Sandberg, 1991). These micro-organisms may occur naturally on the surface of cereals and legumes or can be introduced via inoculation with a starter culture. The extent of the reduction in higher inositol phosphate levels depends on the type of fermentation; sometimes $\geq 90 \%$ phytate can be removed by fermentation of maize, soyabeans, sorghum, cassava, cocoyam (Colocasia esculenta), cowpeas (Vigna unguiculata) and lima beans (Phaseolus limensis; Marfo et al. 1990; Sandberg, 1991; Svanberg et al. 1993). Fermentation of bread dough with yeast also induces phytate hydrolysis, although if $\mathrm{Ca}$ is added as a fortificant phytase activity in yeast is inhibited (Hallberg et al. 1991).

Organic acids are also produced during fermentation and can potentially enhance $\mathrm{Fe}$ and $\mathrm{Zn}$ absorption via the formation of soluble ligands (Charlton, 1983; Hazell \& Johnson, 1987; Walter et al. 1998; Porres et al. 2001). They may also complex some of the minerals bound to phytate molecules, rendering them more susceptible to hydrolysis via phytase enzymes (Maenz et al. 1999), while simultaneously generating a $\mathrm{pH}$ that optimizes the activity of intrinsic phytase from cereal or legume flours (Porres et al. 2001). In contrast, organic acids may have an inhibitory effect on the activity of the intestinal brush-border enzyme glutamate caroboxypeptidase II, attributed to a lowering of the $\mathrm{pH}$ (McNulty \& Pentieva, 2004).

Improvements in protein quality have also been documented after fermenting blended mixtures of plant-based complementary foods based on maize and legumes (Nnam, 1999), groundnuts (Apios americana Medic), pumpkin (Cucurbita Pepo) and millet seeds (Ezeji \& Ojimelukwe, 1993) and cereal and soyabean blends (Sanni et al. 1999). Such improvements may be associated with the destruction by microbial enzymes of protein inhibitors that interfere with $\mathrm{N}$ digestibility (Nnam, 1999), or from the ability of starter cultures to synthesize certain amino acids (Odunfa, 1985).

Soaking. The soaking of cereal and most legume flours in water results in the passive diffusion of water-soluble sodium, potassium or magnesium phytate, which can be removed by decanting the water (De Boland et al. 1975; Chang et al. 1977; Perlas \& Gibson, 2002). Nevertheless, the extent of the removal depends on the species, $\mathrm{pH}$ and length and conditions of soaking. Reductions in the pentaand hexaphosphates of 47,57 and $98 \%$ respectively have been reported for mungbean, maize and rice flours after soaking (Hotz \& Gibson, 2001; Perlas \& Gibson, 2002; Temple et al. 2002); however, no reductions are achieved after soaking whole mungbeans and maize kernels for $6 \mathrm{~h}$ (Perlas \& Gibson, 2002; Temple et al. 2002). Reductions in the content of other anti-nutrients such as glycosides, alkaloids, oligosaccharides, saponins, polyphenols and oxalates may also occur (Chang et al. 1977).

\section{Application of household processing and preparation strategies to enhance nutrient bioavailability of plant foods in developing countries}

There is an urgent need to improve the nutritional quality of plant-based foods in developing countries, especially those used for feeding infants and young children. In the past the emphasis has been on enhancing their protein quality by blending cereals with legumes (usually in ratios of $70: 30(\mathrm{w} / \mathrm{w})$ to provide the optimal mixture of essential amino acids), and problems associated with mineral bioavailability have often been ignored. This approach is unfortunate because many of these cereal-legume blends have a very high phytate content and high phytate: $\mathrm{Zn}$ and phytate: Fe molar ratios.

The inhibitory effect of phytate on $\mathrm{Zn}$ absorption follows a dose-dependent response (Navert et al. 1985) and the molar ratio for phytate: $\mathrm{Zn}$ in the diet is used to estimate the proportion of absorbable $\mathrm{Zn}$ (Oberleas \& Harland, 1981). For Fe, phytic acid begins to lose its inhibitory effect on $\mathrm{Fe}$ absorption when ratios are $<1 \cdot 0: 1 \cdot 0$ and it still inhibits $\mathrm{Fe}$ absorption at ratios as low as $0 \cdot 2: 1 \cdot 0$ (Hallberg et al. 1989; Hurrell et al. 1992).

Both in vitro and in vivo methods have been used to estimate the bioavailability of $\mathrm{Fe}, \mathrm{Zn}$ and $\mathrm{Ca}$ in plant foods. Some in vitro methods are based on a two-stage simulated digestive process of the food or test meal, followed by determination of the dialysable $\mathrm{Fe}, \mathrm{Zn}$ or $\mathrm{Ca}$ released. In general, the magnitude of the responses measured using these methods are not the same as those observed in human subjects, but some of these methods have been used to rank foods with respect to the effect of processing and preparation practices on mineral bioavailability (Latunde-Dada et al. 1998). For example, increases in dialysable $\mathrm{Fe}, \mathrm{Zn}$ and $\mathrm{Ca}$ have been reported after processing porridges prepared from legumes such as chickpea (Cicer arietinum) and black gram (Phaseolus mungo) flours and/or cereal flours such as maize, sorghum and rice by fermentation with a starter culture (Svanberg et al. 1993; Jood \& Kapoor, 1997; Sharma \& Khetarpaul, 1998) and/or by soaking and germination (Svanberg et al. 1993; Mbithi-Mwikya et al. 2002).

More recently, cultured human intestinal cells (i.e. a Caco-2 cell in vitro model) have been developed for studying the characteristics of $\mathrm{Fe}$, and in some cases $\mathrm{Zn}$ and $\mathrm{Ca}$, transport by the intestinal absorptive epithelium (Han et al. 1994; Wortley et al. 2005). However, currently, there is no standardized Caco- 2 cell method and the magnitude of the effects observed appears to depend on the procedures used, making inter-laboratory comparisons difficult. Studies have applied this technique to screen and 
rank selected staple-food genotypes for bioavailable $\mathrm{Fe}$ (Van Campen \& Glahn, 1999), but further development of the Caco-2 cell model is needed before it can be used to determine the bioavailability of $\mathrm{Zn}$ and provitamin $\mathrm{A}$ carotenoids in plant foods.

To date, in vivo isotope studies to measure the bioavailability of $\mathrm{Fe}$ or $\mathrm{Zn}$ in plant foods modified using household strategies to enhance Fe or $\mathrm{Zn}$ absorption are limited. Studies on adults have demonstrated increases in $\mathrm{Fe}$ and $\mathrm{Zn}$ absorption when they are fed porridges used for infant feeding that have been prepared from a variety of dephytinized cereals as compared with those containing their native phytate. In a study of $\mathrm{Fe}$ absorption (Hurrell et al. 2003) phytic acid was degraded by the addition of exogenous commercial phytase enzyme, whereas in a $\mathrm{Zn}$ absorption study (Egli et al. 2004) dephytinization of a wheat-soyabean blend was achieved by the use of phytase naturally occurring in wholegrain cereals (Egli et al. 2003). In a hospital-based study in Malawi (Manary et al. 2000) the reduction of phytate in a maize-soyabean porridge by using a commercial phytase enzyme has been shown to increase fractional and total $\mathrm{Zn}$ absorption and reduce endogenous $\mathrm{Zn}$ losses in children recovering from tuberculosis but has no effect on $\mathrm{Zn}$ absorption in apparentlywell children.

Only a few community-based efficacy trials have assessed the impact of food-based strategies in the household designed to enhance nutrient bioavailability. Early studies focused on improving the bioavailability of nonhaem-Fe have been reviewed by Ruel (2001). More recent studies have measured various outcomes, including absorption in vivo using stable isotopes of Fe (Diaz et al. 2003), nutrient adequacy (Gibson et al. 2003; Hotz \& Gibson, 2005) and biochemical and/or functional health outcomes (Dewey et al. 1997; Manary et al. 2002b; Yeudall et al. 2002; Garcia et al. 2003; Mamiro et al. 2004).

In a recent study in rural Mexico no improvement in biochemical Fe status was observed among Fe-deficient women receiving $25 \mathrm{mg}$ ascorbic acid from fresh lime juice twice daily on $6 \mathrm{~d}$ /week for 8 months compared with those receiving a placebo (Garcia et al. 2003), despite a twofold increase in $\mathrm{Fe}$ absorption, based on earlier stable-isotope results (Diaz et al. 2003). Similarly, after withholding coffee for 5 months no positive effect on Fe status was observed among Fe-deficient Guatemalan toddlers, except among those taking Fe supplements (Dewey et al. 1997), attributed to the relatively small amount of coffee ingested. Furthermore, in a large community-based double-blind randomized controlled trial in Tanzania (Mamiro et al. 2004), in which a processed complementary food (based on soaked and germinated finger millet (Eleusine coracana) and kidney beans (Phaseolus vulgaris), with roasted peanuts (Arachis hypogea) and mango (Mangifera indica L.) puree) and an identical unprocessed blend were fed to 6-month-old infants (n 309) for 6 months, no significant differences were found between the two groups at the end of the study in either $\mathrm{Fe}$ status, as measured by $\mathrm{Hb}$ and zinc protoporphyrin, or growth, perhaps in part because there was only a $34 \%$ reduction in the phytate content of the processed complementary food.
These results emphasize that an integrated approach that combines a variety of the strategies discussed earlier, including the addition of even a small amount of animalsource foods, is probably the best strategy to improve the nutrient bioavailability in diets based on plant foods. Two such community-based efficacy trials have been undertaken among weanlings and young children in rural Malawi. Both trials employed a quasi-experimental design with non-equivalent control groups and used a participatory approach to implement a combination of food-based strategies in the household to enhance their awareness, feasibility and acceptability to caregivers in the local community. Details of the strategies and their implementation have been published (Gibson et al. 1998, 2003; Yeudall et al. 2002, 2005; Hotz \& Gibson, 2005); their efficacy was evaluated by determining knowledge, trial and adoption of the new practices and comparing dietary quality and the adequacy of the energy and nutrient intakes of the intervention and control groups post-intervention (Gibson et al. 2003; Hotz \& Gibson, 2005) and, for the children only, changes in growth and body composition, morbidity and $\mathrm{Hb}$ and hair $\mathrm{Zn}$ concentrations (Yeudall et al. 2002).

Results of the Malawian studies suggest that a combination of household food-based strategies, comparable with those outlined earlier, can be designed to be feasible and acceptable to caregivers of weanlings and children in subsistence farming settings, although on-going nutrition education and social marketing efforts are required to enhance their adoption and to empower the community to sustain them. Nevertheless, even when such a combination of strategies is used, they are probably not sufficient to overcome the deficits in $\mathrm{Ca}, \mathrm{Fe}$ and $\mathrm{Zn}$, and possibly other micronutrients that exist in complementary diets in low-resource settings. In such cases additional strategies to enhance the micronutrient adequacy of these complementary diets are urgently required. Possible strategies include fortifying cereal-based dephytinized complementary foods with a fortificant containing balanced and physiological levels of multi-micronutrients. In the long term, biofortification of staple cereals involving strategies to enhance both micronutrient density and bioavailability may become a feasible option for improving the micronutrient status of the entire household in poor-resource settings.

\section{References}

Bjorn-Rasmussen E \& Hallberg L (1979) Effect of animal proteins on the absorption of food iron in man. Nutrition and Metabolism 23, 192-202.

Bravo L (1998) Polyphenols: chemistry, dietary sources, metabolism, and nutritional significance. Nutrition Reviews 56, 317-333.

Brune ML, Rossander L \& Hallberg L (1989) No intestinal adaptation to a high-phytate diet. American Journal of Clinical Nutrition 49, 542-545.

Camacho L, Sierra C, Campos R, Guzman E \& Marcus D (1992) Nutritional changes caused by germination of legumes commonly eaten in Chile. Archivos Latinoamericanos de Nutricion 42, 283-290. 
Castenmiller JJM, van de Poll, West CE, Brouwer IA, Thomas CMG \& van Dusseldorp M (2000) Bioavailability of folate from processed spinach in humans. Annals of Nutrition and Metabolism 44, 163-169.

Chang R, Schwimmer S \& Burr HK (1977) Phytate: removal from whole dry beans by enzymatic hydrolysis and diffusion. Journal of Food Science 42, 1098-1101.

Charlton RW (1983) The effects of organic acids, phytates and polyphenols on the absorption of iron from vegetables. British Journal of Nutrition 49, 331-342.

Cheryan M (1980) Phytic acid interactions in food systems. CRC Critical Reviews in Food Science and Nutrition 13, 297-335.

De Boland AR, Garner GB \& O'Dell BL (1975) Identification and properties of phytate in cereal grains and oilseed products. Journal of Agricultural and Food Chemistry 23, 1186-1189.

Demigne C, Levrat MA, Younes H \& Remesy C (1995) Interactions between large intestine fermentation and dietary calcium. European Journal of Clinical Nutrition Suppl 3, S235-S238.

Dewey KG, Romero-Abal ME, Quan de Serrano J, Bulux J, Peerson JM, Engle P \& Solomons N (1997) Effects of discontinuing coffee intake on iron status of iron-deficient Guatemalan toddlers: A randomized intervention study. American Journal of Clinical Nutrition 66, 168-176.

Diaz M, Rosado JL, Allen LH, Abrams SA \& Garcia OP (2003) The efficacy of a local ascorbic-acid rich food to improve iron absorption from Mexican diets: a field study using stable isotopes. American Journal of Clinical Nutrition $\mathbf{7 8}$ 436-440.

Egli I, Davidsson L, Juillerat M-A, Barclay D \& Hurrell RF (2002) The influence of soaking and germination on the phytase activity and phytic acid content of grains and seeds potentially useful for complementary feeding. Journal of Food Science 67, 3484-3488.

Egli I, Davidsson L, Juillerat M-A, Barclay D \& Hurrell RF (2003) Phytic acid degradation in complementary foods using phytases naturally occurring in whole grain cereals. Journal of Food Science 68, 1855-1859.

Egli I, Davidsson L, Zeder C, Walczyk T \& Hurrell R (2004) Dephytinization of a complementary food based on wheat and soy increases zinc, but not copper apparent absorption in adults. Journal of Nutrition 134, 1077-1080.

Erdman JW \& Pneros-Schneier AG (1994) Factors affecting nutritive value in processed foods. In Nutrition in Health and Disease, pp. 1569-1578 [ME Shils, JA Olson and M Shile, editors]. Philadelphia, PA: Lea \& Febiger.

Ezeji C \& Ojimelukwe PC (1993) Effect of fermentation on the nutritional quality and functional properties of infant food formulations prepared from bamarra-groundnut, flutedpumpkin and millet seeds. Plant Foods for Human Nutrition 44, 267-276.

Fairweather-Tait S \& Hurrell RF (1996) Bioavailability of minerals and trace elements. Nutrition Research 9, 295-324.

Gaitan E (1990) Goitrogens in food and water. Annual Review of Nutrition 10, 21-39.

Gallagher DD \& Schneeman BO (2001) Dietary fiber. In Present Knowledge in Nutrition, pp. 83-91 [BA Bowman and RM Russell, editors]. Washington, DC: International Life Sciences Institute.

Garcia OP, Diaz M, Rosado JL \& Allen LH (2003) Ascorbic acid from lime juice does not improve the iron status of irondeficient women in rural Mexico. American Journal of Clinical Nutrition 78, 267-273.

Gibson RS \& Ferguson EL (1998) Food processing methods for improving the zinc content and bioavailability of homebased and commercially available complementary foods. Micronutrient Interactions: Impact on Child Health and
Nutrition, pp. 50-57. Washington, DC: International Life Sciences Institute Press.

Gibson RS, Yeudall F, Drost N, Mitimuni B \& Cullinan T (1998) Dietary interventions to prevent zinc deficiency. American Journal of Clinical Nutrition 68, 484S-487S.

Gibson RS, Yeudall F, Drost N, Mitimuni BM \& Cullinan TR (2003) Experiences of a community-based dietary intervention to enhance micronutrient adequacy of diets low in animal source foods and high in phytate: a case study in rural Malawian children. Journal of Nutrition 133, 3992S-3999S.

Hallberg L (1981) Bioavailability of dietary iron in man. Annual Review of Nutrition 1, 123-147.

Hallberg L, Brune M, Erlandsson M, Sandberg AS \& RossanderHulten L (1991) Calcium: effect of different amounts on nonheme and heme-iron absorption in humans. American Journal of Clinical Nutrition 53, 112-119.

Hallberg L, Brune M \& Rossander L (1989) Iron absorption in man: ascorbic acid and dose-dependent inhibition by phytate. American Journal of Clinical Nutrition 49, 140-144.

Han O, Failla ML, Hill AD, Morris ER \& Smith JC (1994) Inositol phosphates inhibit uptake and transport of iron and zinc by a human intestinal cell line. Journal of Nutrition 124, 580-587.

Hazell T \& Johnson IT (1987) In vitro estimation of iron availability from a range of plant foods: influence of phytate, ascorbate and citrate. British Journal of Nutrition 57, 223-233.

Heaney RP (2000) Dietary protein and phosphorus do not affect calcium absorption. American Journal of Clinical Nutrition $\mathbf{7 2}$ 758-761.

Heaney RP, Weaver CM \& Fitzsimmons ML (1991) Soybean phytate content: effect on calcium absorption. American Journal of Clinical Nutrition 53, 745-747.

Hilker DM \& Somogyi JC (1982) Antithiamins of plant origin: their chemical nature and mode of action. Annals of the New York Academy of Sciences 378, 137-145.

Hotz C \& Gibson RS (2001) Assessment of home-based processing methods to reduce phytate content and phytate/ zinc molar ratios of white maize (Zea mays). Journal of Agricultural and Food Chemistry 49, 692-698.

Hotz C \& Gibson RS (2005) A participatory nutrition education intervention improves the adequacy of complementary diets of rural Malawian children: a pilot study. European Journal of Clinical Nutrition 59, 226-237.

Hurrell RF (2003) Influence of vegetable protein sources on trace element and mineral bioavailability. Journal of Nutrition 133, 2973S-2977S.

Hurrell RF, Juillerat MA, Reddy MB, Lynch SR, Dassenko SA \& Cook JD (1992) Soy protein, phytate, and iron absorption in humans. American Journal of Clinical Nutrition 56, 573-578.

Hurrell RF, Lynch S, Bothwell T, Cori H, Glahn R, Hertrampf E et al. (2004) Enhancing the absorption of fortification iron. A SUSTAIN Task Force report. International Journal of Vitamin and Nutrition Research 74, 387-401.

Hurrell RF, Reddy MB, Burri J \& Cook JD (2002) Phytate degradation determines the effect of industrial processing and home cooking on iron absorption from cereal-based foods. British Journal of Nutrition 88, 117-123.

Hurrell RF, Reddy MB, Juillerat M-A \& Cook JD (2003) Degradation of phytic acid in cereal porridges improves iron absorption by human subjects. American Journal of Clinical Nutrition 77, 1213-1219.

Jackson M (1997) The assessment of bioavailability of micronutrients: introduction. European Journal of Clinical Nutrition 51, S1-S2.

Jood S \& Kapoor AC (1997) Improvement in bioavailability of minerals of chickpea and blackgram cultivars through 
processing and cooking methods. International Journal of Food Sciences and Nutrition 48, 307-312.

Kataria A, Chauhan BM \& Gandhi S (1989) Antinutrients and protein digestibility (in vitro) of mungbean as affected by domestic processing and cooking. Food Chemistry 32, 9-17.

Khan N, Zaman R \& Elahi M (1991) Effect of heat treatment on the phytic acid content of maize products. Journal of the Science of Food and Agriculture 54, 153-156.

Latunde-Dada GO, Bianchi MLP \& de Oliviera JED (1998) On the methods for studying the mechanisms and bioavailability of iron. Nutrition Reviews 56, 76-80.

Levander OA (1987) A global view of human selenium nutrition. Annual Review of Nutrition 7, 227-250.

Lönnerdal B (2000) Dietary factors influencing zinc absorption. Journal of Nutrition 130, 1378S-1383S.

Lönnerdal B, Sandberg A-S, Sandström B \& Kunz C (1989) Inhibitory effects of phytic acid and other inositol phosphates on zinc and calcium absorption in suckling rats. Journal of Nutrition 119, 211-214

McNulty H \& Pentieva K (2004) Folate bioavailability. Proceedings of the Nutrition Society 63, 529-536.

Maenz DD, Engele-Schaan CM, Newkirk RW \& Classen HL (1999) The effect of mineral chelators on the formation of phytase-resistant and phytase-susceptible forms of phytic acid in solution and in slurry of canola meal. Animal Feed Science and Technology 81, 177-192.

Mamiro PS, Kolsteren PW, van Camp JH, Roberfroid DA, Tatala S \& Opsomer AS (2004) Processed complementary food does not improve growth or hemoglobin status of rural Tanzanian infants from 6-12 months of age in Kilosa District, Tanzania. Journal of Nutrition 134, 1084-1090.

Manary MJ, Hotz C, Krebs NF, Gibson RS, Westcott JE, Arnold T, Broadhead RL \& Hambidge KM (2000) Dietary phytate reduction improves zinc absorption in Malawian children recovering from tuberculosis but not in well children. Journal of Nutrition 130, 2959-2964.

Manary MJ, Hotz C, Krebs NF, Gibson RS, Westcott JE, Broadhead RL \& Hambidge KM (2002a) Zinc homeostasis in Malawian children consuming a high-phytate, maizebased diet. American Journal of Clinical Nutrition 75, 10571061.

Manary MJ, Krebs NF, Gibson RS, Broadhead RL \& Hambidge KM (2002b) Community-based dietary phytate reduction and its effect on iron status in Malawian children. Annals of Tropical Paediatrics 22, 133-136.

Marfo EK, Simpson BK, Idowu JS \& Oke OL (1990) Effect of local food processing on phytate levels in cassava, cocoyam, yam, maize, sorghum, rice, cowpea, and soybean. Journal of Agricultural and Food Chemistry 38, 1580-1585.

Matuschek E \& Svanberg U (2004) Enzymatic treatment of high-tannin sorghum increases the bioaccessibility of iron. Abstr Th37. Report of the 2004 International Nutritional Anemia Consultative Group Symposium: Iron Deficiency in Early Life: Challenges and Progress, Lima, Peru, p. 60. Washington, DC: INACG; available at http://inacg.ilsi.org/file/ INACGPeru-FINALREPORT.pdf

Mbithi-Mwikya S, van Camp J, Mamiro PRS, Ooghe W, Kolsteren P \& Huyghebaert A (2002) Evaluation of the nutritional characteristics of a finger millet based complementary food. Journal of Agricultural and Food Chemistry 50, 30303036.

Morris ER \& Ellis R (1985) Bioavailability of dietary calcium. In Nutritional Bioavailability of Calcium, pp. 63-72 [C Kies, editor]. Washington, DC: American Chemical Society.

Murray-Kolb LE, Welch R, Theil EC \& Beard JL (2003). Women with low iron stores absorb iron from soybeans. American Journal of Clinical Nutrition 77, 180-184.
Mutanen M \& Mykkanen HM (1985) Effect of ascorbic acid supplementation on selenium bioavailability in humans. Human Nutrition Clinical Nutrition 39, 221-226.

Navert B, Sandstrom B \& Cederblad A (1985) Reduction of the phytate content of bran by leavening in bread and its effect on zinc absorption in man. British Journal of Nutrition 53, 47-53.

Nnam NM (1999) Nitrogen and mineral utilization of young children fed blends of fermented or unfermented corn (Zea may. L), African yam bean (Spenostylis stenocarpa) and cowpea (Vigna unguiculata) Ecology of Food and Nutrition 38, 21-34

Oberleas D \& Harland BF (1981) Phytate content of foods: effect on dietary zinc bioavailability. Journal of the American Dietetic Association 79, 433-436.

O'Dell BL, de Bowland AR \& Koirtyohann SR (1972) Distribution of phytate and nutritionally important elements among the morphological components of cereal grains. Journal of Agricultural and Food Chemistry 20, 718-721.

Odunfa SA (1985) African fermented foods. In Microbiology of Food Fermentations, pp. 151-191 [BJB Wood, editor]. London: Applied Science Publishers.

Offenbacher E (1994) Promotion of chromium absorption by ascorbic acid. Trace Elements and Electrolytes 11, 178-181.

Perlas L \& Gibson RS (2002) Use of soaking to enhance the bioavailability of iron and zinc from rice-based complementary foods used in the Philippines. Journal of the Science of Food and Agriculture 82, 1115-1124.

Porres JM, Etcheverry P \& Miller DD (2001) Phytate and citric acid supplementation in whole-wheat bread improves phytatephosphorus release and iron dialyzability. Journal of Food Science 66, 614-619.

Rock CL, Lovalvo JL, Emenhiser C, Ruffin MT, Flatt SW \& Schwartz SJ (1998) Bioavailability of $\beta$-carotene is lower in raw than in processed carrots and spinach in women. Journal of Nutrition 128, 913-916.

Ruel MT (2001) Can Food-based Strategies Help to Reduce Vitamin A and Iron Deficiencies? A Review of Recent Evidence. Food Policy Review no. 5. Washington, DC: International Food Policy Research Institute.

Sandberg A-S (1991) The effect of food processing on phytate hydrolysis and availability of iron and zinc. In Nutritional and Toxicological Consequences of Food Processing, pp. 499-508 [M Friedman, editor]. New York: Plenum Press.

Sandberg A-S, Brune M, Carlsson N-G, Hallberg L, Skoglund E \& Rossander-Hulthen L (1999) Inositol phosphates with different numbers of phosphate groups influence iron absorption in humans. American Journal of Clinical Nutrition 70, 240-246.

Sandström B (1997) Bioavailability of zinc. European Journal of Clinical Nutrition 51, S17-S19.

Sandström B (2001) Micronutrient interactions: effects on absorption and bioavailability. British Journal of Nutrition $\mathbf{8 5}$, S181-S185.

Sandström B, Davidsson L, Cederblad A \& Lönnerdal B (1985) Oral iron, dietary ligands and zinc absorption. Journal of Nutrition 115, 411-414.

Sandström B, Madsen E \& Cederblad A (1993) Rate of endogenous zinc excretion at high phytate intake. In Proceedings of the 8th International Symposium on Trace Elements in Man and Animals, pp. 620-624 [M Anke, D Meissner and CF Mills, editors]. Gersdorf, Germany: Verlag Media Touristik.

Sanni A, Onilude AA \& Ibidapo OT (1999) Biochemical composition of infant weaning food fabricated from fermented blends of cereal and soybean. Food Chemistry 65, 35-39.

Savage GP (2002) Oxalates in human foods. Proceedings of the Nutrition Society of New Zealand 27, 4-24.

Sharma A \& Khetarpaul N (1998) Development of products incorporating fermented rice-legume-whey blends: effect on 
phytic acid content and availability (in vitro) of calcium and iron. Ecology of Food and Nutrition 36, 491-500.

Svanberg U, Lorri W \& Sandberg A-S (1993) Lactic fermentation of non-tannin and high-tannin cereals: effects on in vitro estimation of iron availability and phytate hydrolysis. Journal of Food Science 58, 408-412.

Temple L, Gibson RS \& Hotz C (2002) Use of soaking and enrichment for improving the content and bioavailability of calcium, iron and zinc in complementary foods and diets of rural Malawian weanlings. Journal of Food Science 67, 1926-1932.

Teucher B, Olivares M \& Cori H (2004) Enhancers of iron absorption: ascorbic acid and other organic acids. International Journal for Vitamin and Nutrition Research 74, 403-419.

Turnlund JR, Swanson CA \& King JC (1983) Copper absorption and retention in pregnant women fed diets based on animal and plant proteins. Journal of Nutrition 113, 2346-2352.

Van Campen DR \& Glahn RP (1999) Micronutrient bioavailability techniques: accuracy, problems and limitations. Field Crops Research 60, 93-113.

van het Hof KH, de Boer BCJ, Tijburg LBM, Lucius BRHM, Zijp I, West CE, Hautvast JGAJ \& Weststrate JA (2000) Carotenoid bioavailability in humans from tomatoes processed in different ways determined from the carotenoid response in the triglyceride-rich lipoprotein fraction of plasma after a single consumption and in plasma after four days of consumption. Journal of Nutrition 130, 1189-1196.

Walter A, Rimbach G, Most E \& Pallauf J (1998) Effect of citric acid supplements to a maize-soya diet on the in vitro availability of minerals, trace elements, and heavy metals. Zentralblatt Veterinarmedizin 45A, 517-524.

Wortley G, Leusner S, Good C, Gugger E \& Glahn R (2005) Iron availability of a fortified processed wheat cereal: a comparison of fourteen iron forms using an in vitro digestion/human colonic adenocarcinoma (CaCo-2) cell model. British Journal of Nutrition 93, 65-71.

Yeudall F, Gibson RS, Cullinan TR \& Mitimuni B (2005) Efficacy of a community-based dietary intervention to enhance micronutrient adequacy of high-phytate maize-based diets of rural Malawian children. Public Health Nutrition 8, 826-836.

Yeudall F, Kayira C, Umar E \& Gibson RS (2002) Impact of a community-based dietary intervention on selected biochemical and functional outcomes in rural Malawian children. European Journal of Clinical Nutrition 56, 1176-1185.

Yeum K-J \& Russell RM (2002) Carotenoid bioavailability and bioconversion. Annual Review of Nutrition 22, 483-504. 